\title{
Relationship between lipid and protein oxidation in fish
}

\author{
Nima Hematyar ${ }^{1}$ (D) | Turid Rustad ${ }^{2}$ (D) | Sabine Sampels ${ }^{1,3}$ (D) | Trine Kastrup Dalsgaard ${ }^{4}$ (ID
}

${ }^{1}$ Faculty of Fisheries and Protection of Waters, South Bohemian Research Center of Aquaculture and Biodiversity of Hydrocenoses, Institute of Aquaculture and Protection of Waters, University of South Bohemia in České Budějovice, České Budějovice, Czech Republic

${ }^{2}$ Department of Biotechnology and Food Science, Norwegian University of Science and Technology, Trondheim, Norway

${ }^{3}$ Department of Molecular

Sciences, Swedish University of Agricultural Sciences, Uppsala, Sweden

${ }^{4}$ Department of Food Science, Aarhus University, Tjele, Denmark

\section{Correspondence}

Nima Hematyar, Faculty of Fisheries and Protection of Waters, South Bohemian Research Center of Aquaculture and Biodiversity of Hydrocenoses, Institute of Aquaculture and Protection of Waters, University of South Bohemia in Ceske Budejovice, České Budějovice, Czech Republic.

Email: hematyar@frov.jcu.cz

Funding information

The Ministry of Education, Youth and Sports of the Czech Republic; The CENAKVA project (LM2018099), CENAKVA Center Development (No. CZ.1.05/2.1.00/19.0380), OPVVV and the project Reproductive and Genetic Procedures for Preserving Fish Biodiversity and Aquaculture (CZ.02.1.01/0. 0/0.0/16_025/0007370).

\begin{abstract}
Reactive oxygen species (ROS) are generated in all aerobic organisms. Free radicals are highly reactive ROS that cause damage to biological materials. Fish is rich in polyunsaturated fatty acids, and hence, very prone to lipid peroxidation. Both lipid and protein oxidations are important for quality loss during storage of fish, with high impact on taste and texture. Also, there are interactions between protein and secondary lipid oxidation products (aldehydes) that occur in foods because the oxidation products from one reaction can further react with both lipids and proteins respectively. This review focuses on the mechanisms and pathways of the lipid and protein oxidation and their possible relationship. Additionally, the target amino acids and final impacts of this relationship were considered. We propose that the products of lipid oxidation promote protein oxidation in fish rather than the other way around specially, during frozen storage, while during postmortem changes protein oxidation dominates. Finally, it seems that, secondary products of lipid oxidation might have more impact on the functionality of proteins from both Michael addition and Schiff base reaction rather than lipid hydroperoxides and lipid radical transfer.
\end{abstract}

\section{KEYWORDS}

fish, free radicals, interaction, Lipid oxidation, protein oxidation

\section{1 | INTRODUCTION}

Oxidation in food is a process that concerns both lipids and proteins by the effect of reactive oxygen species (ROS) (Bernardini et al., 2011). Oxidative modifications can cause numerous functional consequences and lead to changes in food texture, water holding capacity (WHC), digestibility and juiciness in fish meat (Baron, Kjaersgard, Jessen, \& Jacobsen, 2007). Also, Sarma, Reddy, and Srikar (2000) found a negative correlation between lipid oxidation parameters and functional properties of the protein in Indian oil sardine, indicating their interdependence. However, still little is known about the kinetics of protein oxidation, the interaction of protein and lipid oxidation and the subsequent impact on muscle food quality (Baron et al., 2007; Kjaersgard \& Jessen, 2004).

For many years, the focus of food was on lipid oxidation, not only because of its effect on taste and shelf life, but also because the lipid oxidation products can more easily be measured (hydroperoxides, hexanal and MDA) than protein oxidation product and therefore have been detected and correlated to off-flavour in food. Especially in fish, which is rich in $n-3$ polyunsaturated fatty acids (PUFA), there is a high risk of quality loss due to oxidation (Jeremiah, 2001; Medina, Gallardo, \& Aubourg, 2009). Besides lipid oxidation, the oxidation of proteins can also cause quality changes in the fish fillet. In general, the same factors causing lipid oxidation will also cause protein 
oxidation. The kinetics of protein and lipid oxidation with respect to the generation of hydroperoxide and carbonyls are quite similar but the diversity of the protein oxidation products are more complex than those of lipid oxidation due to more reactive targets in the proteins. The progress of initial oxidative reactions in food is enhanced by the interactions between the proteins and lipids due to the similarity of the oxidation reactions. The development of lipid and protein oxidation can occur in parallel or independently, but often there are interactions between them (Zhang, Xiao, \& Ahn, 2013). Several authors reported a good correlation between oxidised products of lipid and protein in fish (Soyer \& Hultin, 2000) beef (Estévez \& Cava, 2004) and chicken (Soyer, Özalp, Dalmış, \& Bilgin, 2010), which indicates that protein and lipid oxidation start together and can interact with each other. In contrast to those conclusions, Aalhus and Dugan (2014) have suggested that the products of lipid oxidation can promote protein oxidation since lipid oxidation may start earlier.

In the initiation of lipid oxidation, products can react with proteins and vice versa, but the most well-described reaction is the reaction between secondary lipid oxidation products and primary amino groups on proteins (Schwenke, 1978; Burcham, \& Kuhan, 1996).

As touched upon above, the reaction between secondary lipid oxidation products and amino acids also takes place in fish. Saturated lipid aldehydes become covalently bound to susceptible and functional groups of proteins like N-terminal groups of Tyr, Asp, Arg and Met (Metz et al., 2004), the $\epsilon-\mathrm{NH} 2$ group of Lys and Cys-SH (Metz et al., 2004) through a Schiff base formation while unsaturated aldehydes also can react via Michael addition (Cai, Bhatnagar, \& Pierce, 2009). By these interactions proteins hydrophobicity and aggregation are increased in fish flesh. In addition, the progress of lipid oxidation in fish muscle strongly correlates to the formation of metHb/metMb and also leads to the reduction in extractability haem proteins. For example, during frozen storage of herring fillets, peroxide value (PV) and thiobarbituric acid reactive substances were increased while the amount of haem-proteins decreased (Jonsson et al., 2007).

This review aims to give an overview of the lipid and protein oxidation, the known pathways and correlations between lipid and protein oxidation in raw and postmortem conditions and also the effects of oxidation with a special focus on fish fillet quality.

\section{MECHANISMS OF LIPID AND PROTEIN OXIDATION}

In order to investigate lipid-protein correlations in fish fillet, the mechanisms of lipid and protein oxidation should be understood in depth. Particularly, the control of possible catalysts has a key role because free radical chain reactions can be swiftly boosted by catalysts.

Lipid oxidation is a key factor, leading to a decline in food quality, predominantly of those food products, which contain high amounts of unsaturated fatty acids (Secci \& Parisi, 2016). Generally, the potential initiators of lipid oxidation can also initiate the protein oxidation (Xiong, 2000). However, the mechanisms, pathways and also the products of protein oxidation are different (Stadtman, 2006).
The functional groups, which are located in the amino acid residues side chain and the peptide backbone are the targets for ROS.

The effect of lipid oxidation in muscle food (Estévez \& Cava, 2004) and seafood (Secci \& Parisi, 2016; Mariutti, \& Bragagnolo, 2017) and protein oxidation (Estévez, 2015; Soladoye, Juarez, Aalhus, Shand, \& Estevez, 2015) has been reviewed extensively whereas correlation between the lipid and protein oxidation has not really been touched upon in a review.

\section{1 | Lipid oxidation}

Unpleasant off-flavours and formation of volatiles can develop due to the oxidation of PUFA. The most important factors which can affect rancidity in fish muscle are the high content of PUFA and also the presence of pro-oxidants, especially the parts containing haem groups (Richard, \& Hultin, 2002).

Autoxidation enzymatic catalysed oxidation and photosensitized oxidation are three major mechanisms in lipid oxidation.

Autoxidation in meat and fish can be initiated by light, heat and the presence of metal ions and radicals (Sampels, 2013). Autoxidation leads to the formation of the primary oxidation products, hydroperoxides $(\mathrm{ROOH})$. Once the oxidation process has started, a cascade of reactions will occur with each new molecule increasing the reaction speed and variability (Heinonen, Meyer, \& Frankel, 1998). ROOH from lipid oxidation decompose easily at a high temperature or in the presence of metals to secondary products such as aldehydes, short chain hydrocarbons, alcohols, esters, acids and ketones (Choe \& Min, 2006). Finally, termination products can be crosslinking products, for example, where two radicals react with each other, thereby terminating the chain reaction caused by radical reaction.

The atmospheric triplet oxygen is the most common oxygen species involved in the oxidation of lipids but in the photosensitized reaction, both singlet and triple oxygen are two types of oxygen having more interactions with lipids (Foote, 1976), Singlet oxygen has been suggested to react 1,450 times faster with linoleic acids than triplet oxygen (Rawls, \& Santen, 1970). Singlet oxygen is needed to start the so called type II photosensitized oxidation process, which can react with unsaturated lipids (Foote, 1976), but compared with type I reaction the type II reaction generate different types of hydroperoxide products. The greater importance is the energy of oxygen, which has a significant impact on the initiation of the oxidation reaction.

Metal catalysis can be considered as an important lipid oxidation reaction in fish muscle, this means that after post-slaughter processes, the released haem iron (ferrous (+2)) is converted to ferric (+3) and starts the autoxidation progress. Both haem proteins (haemoglobin $[\mathrm{Hb}]$ and myoglobin) can increase the lipid oxidation in fish fillet and other muscle foods (Kanner, 1994). Richards and Hultin (2002) reported that the blood residue in fish fillet, catalyses lipid oxidation during storage of fatty fish and bleeding was also shown to retard lipid oxidation of minced trout muscle during storage at $+2^{\circ} \mathrm{C}$. Maqsood and Benjakul (2011) showed that the initiation and propagation of lipid oxidation in the un-bled samples compared with the bled samples were more marked. 
In addition, there are several enzymes in fish, which are capable of catalysing lipid oxidation such as, lipoxygenases and myeloperoxidases. The first one exists in fish skin and gills and can catalyse the incorporation $\mathrm{O}_{2}$ into an unsaturated fatty acid and generate $\mathrm{ROOH}$, and the second one initiates lipid oxidation in the presence of halides and hydrogen peroxide. During the process, this can be critical because the lipid, oxygen and blood interaction will be increased (Mozuraityte, Kristinova, Rustad, \& Storro, 2016).

\section{2 | Protein oxidation}

Foods are constantly exposed to ROS and this will not only cause lipid oxidation but also protein oxidation. However, for several decades proteins were ignored as a target for ROS, in the opposite of lipid oxidation, which was investigated very deeply. In contrast to lipids, proteins are complex macromolecules arranged in 3D-structures, and when oxidation occurs it leads to various changes in the proteins, both chemical changes on individual amino acids (Davies, Delsignore, \& Lin, 1987) such as Met (Dalsgaard et al., 2010) Tyr (Dalsgaard, Nielsen, Brown, Stadler, \& Davies, 2011) His and Trp (Dalsgaard, Nielsen, \& Larsen, 2007) Lys and Arg (Dalsgaard, Otzen, Nielsen, \& Larsen, 2007; Lund, Heinonen, Baron, \& Estevez, 2011) but also structural changes may occur (Davies \& Delsignore, 1987). Because the functions of protein are very specific, oxidative modifications can cause numerous functional consequences and lead to changes in food texture, WHC, digestibility and juiciness (Baron et al., 2007; Sarma et al., 2000). Protein oxidation may be caused directly by ROS and reactive nitrogen species or indirectly as the result of reactions with products from lipid oxidation with reducing sugars or carbohydrate (Lund et al., 2011). On the other hand, nucleophilic reaction on the carbonyl groups of free sugars and aldehyde on the side chain of amino acids can lead to production of Schiff base products (Dalsgaard, Nielsen, \& Larsen, 2006, Dalsgaard, Otzen et al., 2007). Generally, the pathways of protein carbonylation can be divided to direct oxidation, metal-catalysed oxidation, reaction with free sugars and also lipid peroxidation products (Michael adducts) (Fedorova, Bollineni, \& Hoffmann, 2014). Due to side chain oxidation of some amino acids (Arg, Lys, His and Pro) or backbone oxidation of Asp, Pro and Glu residues carbonylation can be considered as a permanent and destructive (Hawkins \& Davies, 2001) indicator of protein oxidation (Nystrom, 2005).

Protein oxidation is initiated when a hydrogen atom is abstracted from the protein to generate a 0140 carbon-centred radi$\mathrm{cal}(\mathrm{C} \cdot$ ) and in the presence of oxygen is converted to an alkylperoxy radical (COO.). The following reaction of (COO.) with hydrogen atom abstraction from another molecule leads to alkyl peroxide $(\mathrm{COOH})$ formation. Subsequent reactions lead to the formation of the alkoxy radical (CO.) and hydroxyl compounds ( $\mathrm{COH}$ ). In addition, two carbon-centred radicals (alkyl-radical such as ethane, methane and propane) can react with each other in the absence of oxygen to generate carbon-carbon cross-linked derivatives (Papuc, Goran, Predescu, \& Nicorescu, 2017). The termination reaction, which in relation to fish and meat quality may affect tenderness (Soladoye et al., 2015).
Additionally, aromatic amino acids like Tyr, Trp, His and Phe are very susceptible to oxidation (Hawkins \& Davies, 2001). During oxidation of aromatic amino acids, phenoxyl radicals will be formed from tyrosine and their metabolites, dityrosine and other products, are generated. This occurs especially when tyrosine is close to tyrosol radicals and also tyrosyl radicals which cannot be repaired because they are not reductants (Aeschbach, Amadoò, \& Neukom, 1976).

On the other hand, the amino acids, which are aliphatic but do not contain sulphur like Pro or Arg are oxidized via another way. In this group, oxidation takes place by hydrogen abstraction at the $\alpha$ carbon generating a carbon centred radical (Stadtman, 1993). This reaction occurs at the terminal amine of the Lys side-chain and sites distant from deactivate $\alpha$-amino group. The generated product will be different depending on the presence or absence of oxygen (Stadtman, 1993).

Protein oxidation via metal-catalysed cleavages is the main reason of oxidative damage in vivo systems like fish (Moller, Rogowska-Wrzesinska, \& Rao, 2011) and also in the postmortem fish muscle.

In some proteins, metal ion-catalysed oxidation systems can easily oxidize the side-chains of amino acid residues. Lys, Pro and Arg are the most important targets of metal catalysed oxidation (Adolfo Amici, Tsai, \& Stadtman, 1989). Requena, Chao, Levine, and Stadtman, (2001) reported glutamic and then aminoadipic semialdehydes are respectively very important carbonyl products in metal catalysed oxidation systems. For example, Lys can be a target for Fe (II)-catalysed oxidation system. In the mentioned mechanism, the chelate form of Fe (II) and amino group of Lys can generate a hydroxyl radical by a reaction between Lys and hydrogen peroxide. Hydroxyl radical preferentially attacks to the Lys moiety to convert Lys to a 2-amino-adipic-semialdehyde residue. The similar reaction with other amino acids by Fe (II) can produce carbonyl derivatives. The site-specific mechanism is supported by the confirmation that the metal-catalysed reactions are prevented by catalase but not by . $\mathrm{OH}$ scavengers, maybe because the scavengers are not be able to compete with the "caged" reaction at the metal binding site between amino acids and $\cdot \mathrm{OH}$.

Amadori products, which have been generated via Schiff base products rearrangement are highly susceptible to the degradation and metal-catalysed oxidation reaction. Consequences of the reactions lead to protein cross-linked adducts and Maillard reaction products (Lund et al., 2011).

The major mechanisms in protein oxidation are still unclear because there are only a few methods available to evaluate protein oxidation mechanisms, but the number of reaction products is large. Detection of carbonyl groups, the formation of dityrosine and changes in sulphydryl groups are the most common methods to detect and quantify protein oxidation. In addition, there are some advanced methods such as fluorescence spectroscopy, and electron spin resonance, immune-spin trapping in combination with mass spectrometry used to investigate the mechanism of protein oxidation (Dalsgaard et al., 2014). 


\subsection{1 | Function of proteins as antioxidants}

On the other hand, in some cases, proteins besides being the target for oxidation are also known to be able to function as antioxidants. The mechanisms of proteins and amino acids as antioxidants in food have been related to their ability to chelate pro-oxidative metals; sulphydryl groups, which exist in the proteins and amino acids can inactivate free radicals (Viljanen, Kylli, Hubbermann, Schwarz, \& Heinonen, 2005). In some cases, the proteins may act as a shield between ROS and the lipid (Dalsgaard, Sorensen et al., 2011). Carnosine can prevent lipid oxidation in various model systems by free radical scavenging or metal ion chelating (Liu, Xing, Fu, Zhou, \& Zhang, 2016). His residues and carnosine can postpone oxidation by removing metal ions from the surface of other macromolecules (Guiotto, Calderan, Ruzza, \& Borin, 2005). Furthermore, some peptides, which contain Trp or Tyr at the C-terminus have shown to possess a high radical scavenging ability (Saito et al., 2003) and as mentioned above, for example, dityrosine formation as a consequence of two tyrosine radicals reacting with each other will terminate the radical (Dalsgaard, Sorensen et al., 2011). The amount of riboflavin, which is responsible for photo-oxidation is variable in different fish species (Brjekkan, 1959), may play an important role as well. It seems that fish with higher amount of proteins contain more riboflavin. Therefore, Trp and Tyr can be considered as a main target of photo-oxidation in fish fillet, which are the only amino acids that can compete with oxygen or unsaturated fatty acids in the quenching of triplet state riboflavin (Cardoso, Franco, Olsen, Andersen, \& Skibsted, 2004; Dalsgaard, Sorensen et al., 2011). However, the sequence and categories of amino acid might have a key role in the peptides antioxidant activity (Liu et al., 2016). Imidazole ring in the $\mathrm{R}$ group of His has the ability of metal ion-chelating, lipid peroxyl radical trapping and hydrogen donating (Chan \& Decker, 1994). In addition, Pro-His-His sequence showed higher antioxidant ability in the linoleic acid system compared with other synthetic peptides (Liu et al., 2016), while, the mechanism of hydrophobic amino acids such as Trp and Try might differ. The presence of peptides is enhanced at the water-lipid interface which can approach to the lipid phase and scavenge free radicals (Ranathunga, Rajapakse, \& Kim, 2006).

Hence lipid oxidation in fish could also be retarded due to the simultaneous presence of certain proteins and amino acids. However this connection is also still widely unexplored.

\section{3 | IMPACT OF LIPID AND PROTEIN OXIDATION ON FISH FILLET TRAITS}

\section{1 | Lipid oxidation and quality parameters}

Sensory, nutritional value and colour are the major quality characteristics, which can be affected in muscle foods by lipid oxidation. Several authors reported the negative effects of lipid oxidation on the sensory aspect of fish fillet (Baron et al., 2007; Yin, Luo, Fan, $\mathrm{Wu}, \&$ Feng, 2014). Yin et al. (2014) studied effects of frozen storage on grass carp (Ctenopharyngodon idellus) fillet and reported that the sensory parameters (colour, odour, morphology and muscle elasticity) decreased significantly $d$ by the effect of lipid oxidation.

Estévez, Ventanas, and Cava, (2005) reported a significant correlation between lipid oxidation and fat content in liver of pâté. Fat content might have a key role in the development of lipid and protein oxidation in the muscle foods (Estevez, Morcuende, Ventanas, \& Cava, 2003; Stadtman, 1990). In order to find a correlation between fat content and the development of lipid oxidation we compared PV results of two different kinds of fish species (lean and fatty fish). Comparing the studies by Saeed and Howell (2002) and Baron et al. (2007) on Atlantic mackerel (Scomber scombrus) rainbow trout (Oncorhynchus mykiss), respectively, reveals that in fatty fish lipid oxidation started earlier compared with lean fish and PV values were higher during storage at $-20^{\circ} \mathrm{C}$ in fatty fish.

In most fish, the major contributor to the colour of muscle is myoglobin. During storage, ferrous oxymyoglobin $\left(\mathrm{Fe}^{2+}\right)$ oxidized to ferric metmyoglobin $\left(\mathrm{Fe}^{3+}\right)$, which is responsible for a discoloration reaction in fish fillets (Papuc et al., 2017). Secondary lipid oxidation products (aldehydes) can, furthermore, alter the myoglobin structure via covalent bonds and change the fillet colour during the storage time (Lynch \& Faustman, 2000). In addition, brown pigments in fish can be generated via lipid-protein interaction. In this case, lipid peroxide can interact with active types of proteins and lead to the transformation of the light coloured or colourless precursor to brown pigments (Hidalgo \& Zamora, 2000).

\subsection{Consequences of protein oxidation}

The hydrophobicity, solubility, WHC tenderness and texture are the most important quality parameters, which depend directly on protein oxidation in fish fillet (Lund et al., 2011). Oxidation in a side chain of amino acids can produce carbonyl groups that eventually result in a loss of solubility and protein aggregation (Rowe, Maddock, Lonergan, \& Huff-Lonergan, 2004).

\subsection{1 | Hydrophobicity}

Hydrophobic residues, in the native form of proteins, are hidden. In a semi oxidized protein, the alteration of secondary and tertiary of protein structure exposes the hydrophobic residues to the proteases enzyme substrates followed by protein degradation (Jung, Hohn, \& Grune, 2014), while heavy oxidation resulted in protein aggregation via cross-linked proteins (Hohn et al., 2011). Aggregated proteins are stable against enzymatic degradation (Reeg \& Grune, 2015).

\subsubsection{Water holding capacity}

Protein oxidation has a negative effect on the WHC. As the accessibility of the polar groups to pro-oxidants, which are present in fish muscle, is very high, they are more prone to oxidative reactions (Standal et al., 2018). Protein carbonylation leads to the loss of amino groups, which in turn results in the alteration of the distribution of the 
electrical charges and the overall arrangement of myofibril protein. It appears that one result of intensive oxidative protein modification is a change in the isoelectric points of proteins. Therefore, the oppositely charged groups are more attracted to each other and thereby decrease the amount of water that is held by the protein. Moreover, the repulsion of the myofibril protein structures is reduced due to the isoelectric point therefore the protein structures can be more compact and decrease WHC (Huff-Lonergan \& Lonergan, 2005).

\subsection{3 | Tenderness and firmness}

The tenderness of fish fillets can change as a result of protein oxidation. There are two hypotheses for a decrease in tenderness in relation to protein oxidation:

a Amplification of the myofibrillar structure through the formation of MP cross-linking (Kim, Huff-Lonergan, Sebranek, \& Lonergan, 2010) particularly, in the presence of oxygen. Myosin proteins especially, $\mathrm{MHC}$ is susceptible to oxidation due to the presence of $\mathrm{Cys}$ in the root tail of myosin, which is responsible for protein cross-link. The results of this cross-link may decrease the fish muscle tenderness. Glutathionylation of particular Cys in myosin binding protein $\mathrm{C}$ and troponin I might be responsible to change the sensitivity of myofilament to calcium (Patel, Wilder, \& Solaro, 2013). In several studies, myosin has been reported as a target of glutathionylation and also protein oxidation (Passarelli et al., 2010) but still there is a lack of knowledge about the functional and structural alteration in myosin by the effect of specific redox sites.

b $\mu$-Calpain inactivation (Rowe et al., 2004). For peptide bonds hydrolysis by calpains, electron transfer is needed on the active side chain of His and Cys residues. In this case, carbonyl derivatives of some amino acids, such as His, lead to the formation of inter and/or intraprotein disulphide cross-links (Martinaud et al., 1997). Because SHcontaining Cys and His residues are present at the active sites of both $\mu$-calpain and $\mathrm{m}$-calpain enzymes and these products might be inactivated by oxidation and lead to reduce fish muscle tenderness (Carlin, Huff-Lonergan, Rowe, \& Lonergan, 2006).

On the other hand, it has been proved that due to protein oxidation, firmness is reduced during frozen storage by the impact of ice crystal formation and cell disruption (Hematyar, Masilko, Mraz, \& Sampels, 2018; Subbaiah et al., 2015).

It seems that myoglobin and myofibril are the most important proteins to impact on fish quality. Probably, the formation of covalent bonds and cross-links, by the impact of lipids and proteins oxidation are responsible for quality changes in the fish fillet. Therefore, extensive oxidation in fish muscle often leads to higher firmness while moderate protein oxidation can decline the firmness due to more unfolded protein structures. Additionally, degradation and aggregation of proteins in the postmortem fish muscle lead to higher firmness and lower tenderness. On the other hand, during frozen storage formation of unfolded proteins due to oxidation or lipid-protein interaction probably are responsible for reduction in firmness.

\section{4 | CORRELATION AND INTERACTION OF LIPID AND PROTEIN OXIDATION}

During the storage of fish fillet, proteins are exposed to oxidized lipids or secondary breakdown products that may cause some changes in protein functionality including insolubilization, polymerization, loss of enzymatic activity and formation of lipid-protein complexes (Howell, Herman, \& Li-Chan, 2001).

\section{1 | Mechanisms of interaction}

Two mechanisms can be considered for the interaction of lipids-proteins:

a First, hydroperoxide decomposes to secondary lipid oxidation products, for example, malonaldehyde that may react further with amino groups (Schaich \& K. M., 1976) or for unsaturated lipid aldehydes reacting with Cys, His, or Lys through Michael addition (Stadtman \& Levine, 2000).

b Some products of lipid oxidation (hydroperoxides, lipid free radicals and volatile secondary oxidation products) can react with proteins to generate protein-centred free radicals (Saeed, Fawthrop, \& Howell, 1999).

Secondary lipid oxidation products can bind to proteins in two main ways by either binding to an active site or cavity or at less well defined hydrophobic patches at positions close to the surface of the protein (Fillery-Travis, Mills, \& Wilde, 2000). Aldehydes as a product of metal catalysed lipid oxidation cause, protein-lipid aggregation via crosslink bonds (Gardner, 1979). The pathways for the interaction of lipid oxidation products (carbonyls) with proteins are formation of Schiff base and Michael-type (Refsgaard, Tsai, \& Stadtman, 2000). In the carbonyl amine reaction, aldehydes can bind directly to amino groups in proteins through covalent bonds. Interaction of dimethylamine and formaldehyde from trimethylamine-N-oxide may result in decreased WHC as formaldehyde may form crosslinks between proteins, which have been shown to decrease WHC and protein solubility in the Gadiform Fish fillet (Nielsen \& Jorgensen, 2004).

Also, the products of lipid oxidation might have interaction with proteins on the hydrophobic groups site, which lead to generate lipid-soluble fluorescence products. The consequence of this interaction in the defatted samples can be resulted to decline in soluble protein hydrophobicity (Liang, 1999) upon when the secondary and tertiary structure of proteins are changed (Meng, Chan, Rousseau, $\&$ Li-Chan, 2005). This reaction mostly happens in the presence of some prone amino acids such as His, Lys, Pro, Arg, Tyr, Trp, Cys and Met via side chain reaction with lipid oxidation products. As soon as protein unfolding occurs at the water-lipid interface, the hydrophobic groups are absorbed and interact with the lipid phase. While, the negatively charged groups of protein can remain in contact with water molecules and hence increase the solubility or reduce the risk of protein-protein aggregation (Gitlin, Carbeck, \& Whitesides, 2006; Kramer, Shende, Motl, Pace, \& Scholtz, 2012). 


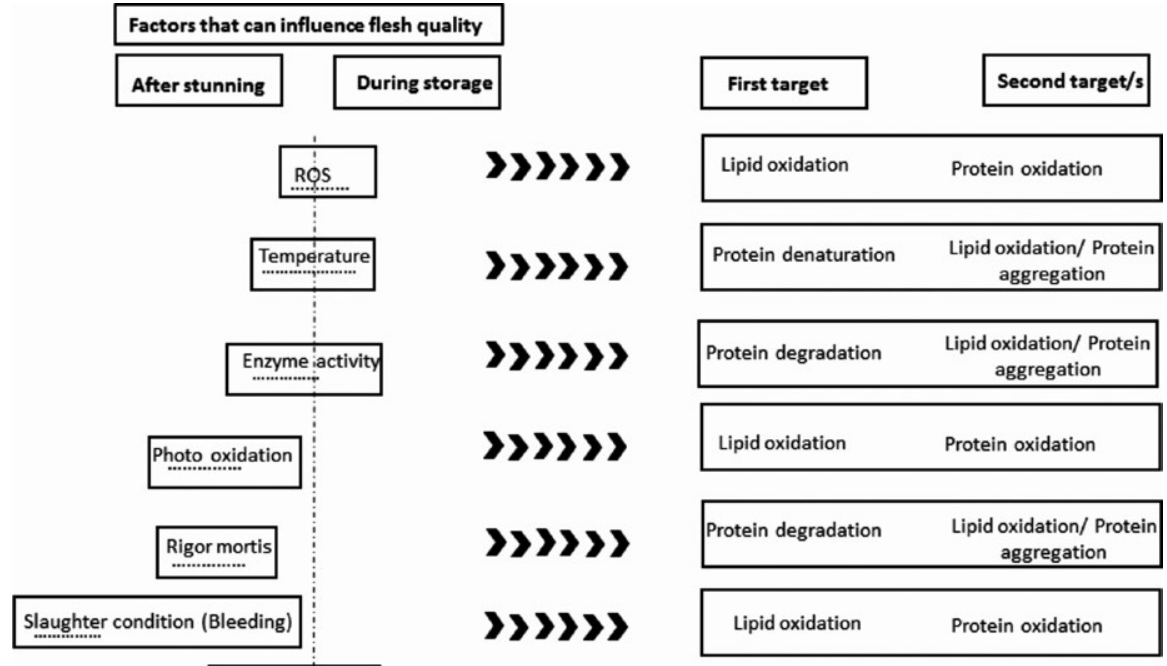

FIGURE 1 Main factors that can influence fish flesh quality before and after storage time and prefer primary and secondary targets. The efficiency of parameters which affect on fish flesh quality in the time period is indicated by dotted lines
Thus, it appears that the covalent bonds are a very important type of bonds between free amino groups of Cys, His and Lys with MDA via side chain pathway (Pizzimenti et al., 2013). For a better understanding of protein-lipid interaction, it is necessary to know more about the water-lipid bonds and also the lipid-protein relationship, as it seems that there is a close relationship between them (Alzagtat \& Alli, 2002). In the frozen fish muscle due to the absence of water molecules, lipidprotein or protein-protein interactions are dominated. Additionally, the interactions depend on the secondary products or radicals predominate that can be specified by which proteins get involved in the lipid oxidation reaction chain (Ladikos \& Lougovois, 1990). Furthermore, the stability of the proteins and volatiles may increase via non-covalent bonds during the storage time of muscle foods.

\subsection{Role of haemoglobin and myoglobin on the progress of lipid oxidation}

It has also been demonstrated in model systems that lipid oxidation can increase in the presence of protein radicals (Østdal, Davies, \& Andersen, 2002). A good example for this kind of interaction in fish muscle has been reported by Richard and Hultin (2002) that revealed oxidized haemoglobin (deoxyhemoglobin) is a powerful catalyst of lipid oxidation.

Haemoglobin $(\mathrm{Hb})$ autoxidation rate in different fish species, might be influenced by their residue (Powers, 1972). Richards and Hultin (2003) revealed that $\mathrm{Hb}$ from mackerel (Scomber scombrus) and herring (Clupea harengus) showed more pro-oxidative activity than from trout (Onchorhynchus mykiss) Hb. This would be related to the frequent migration, which made $\mathrm{Hb}$ more susceptible to autoxidation. Probably, mackerel blood contains more lipid oxidation promoters or less powerful inhibitors (Richards \& Hultin, 2003). However, Maqsood and Benjakul (2011); Maqsood, Singh, Samoon, and Munir (2011) reported that active migratory fish like seabass (Lates calcarifer) had less pro-oxidative $\mathrm{Hb}$. In addition, $\mathrm{Hb}$ autoxidation in the fish from cold water was 10-fold faster than warm water fish (Maqsood \& Benjakul, 2011). His residue may be situated away from the centre making $\mathrm{Hb}$ more resistant to oxidation (Jensen, 2001). Probably, when His and Phe residues are located on the distal part of the haem group the accessibility of iron to the mentioned amino acids is decreased that leads to less interaction between $\mathrm{Hbs}$ and lipid oxidation products. The rate of lipid oxidation can be affected by different Hbs formations in fish flesh (Maqsood, Benjakul, \& Kamal-Eldin, 2012). Richards and Hultin (2002) reported that deoxy $\mathrm{Hb}$ is a stronger catalyst for lipid oxidation compared with $\mathrm{oxyHb}$. Formation of deoxyHb releases the iron from the inside of the porphyrin group, which is a catalyst for lipid oxidation and lipidprotein interaction. Immediate bleeding would keep the freshness of muscle for a longer time and maintenance the fillet firmness during the storage time. It has been demonstrated that inadequately bled or non-bled fish shows lower overall quality in the fish fillet as bleeding decreases the total haemoglobin in the muscle (Richards \& Hultin, 2002).

In fish, myoglobin oxidation and lipid oxidation are associated and influence each other (Chaijan, 2008). Secondary lipid oxidation products (aldehydes) can modify the stability of myoglobin and generate adducts through a covalent modification with myoglobin but in the absence of lipid oxidation products metal catalyse via side chain reaction can unfold the proteins. In line with this, Lynch and Faustman (2000) proposed that pro-oxidant activity of metmyoglobin and oxymyoglobin oxidation will be increased by aldehydes. Furthermore, metmyoglobin and $\mathrm{H}_{2} \mathrm{O}_{2}$, resulting from oxymyoglobin oxidation, can provoke lipid oxidation. In one way the products of oxymyoglobin (metmyoglobin and $\mathrm{H}_{2} \mathrm{O}_{2}$ ) are necessary to start lipid oxidation and on the other way aldehydes can change myoglobin stability and promote oxymyoglobin oxidation.

\section{3 | Myosin-lipid interaction}

Myosin is another protein in fish that has a weak tendency to form a complex with lipids, but the form of myosin can change during the storage due to unfolding. However, linoleic acid hydroperoxides are highly 


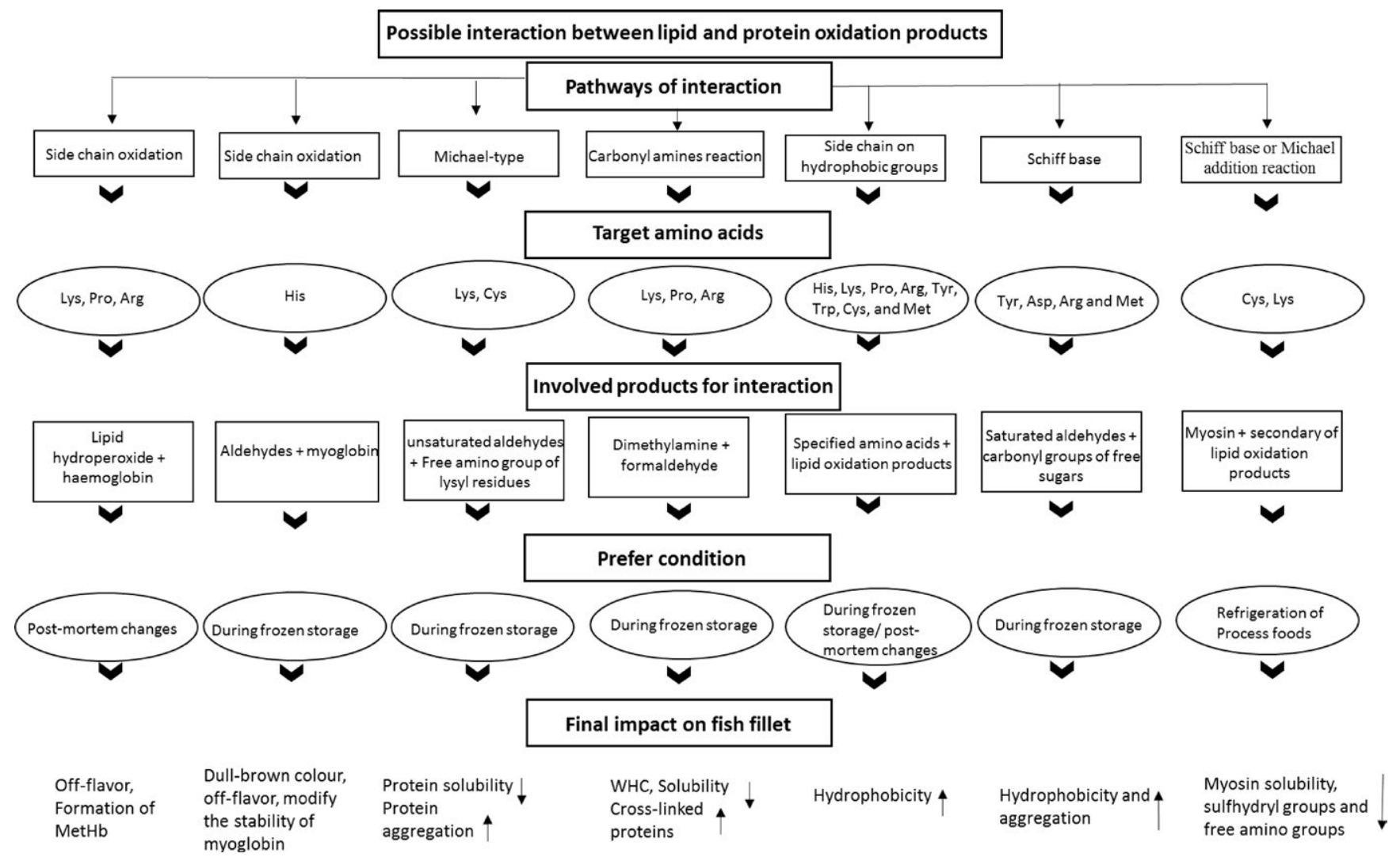

FIGURE 2 The main possible interaction pathways with the target amino acids and involved products of lipid and protein oxidation with respect to the ideal condition. Main impact of the mentioned interaction on the final flesh quality

destructive for myofibrillar structures that can precipitate and denature the A-band (predominantly myosin). Chopin, Kone, and Serot (2007) investigated the interaction between fish myosin and secondary of lipid oxidation products and found a correlation between myosin solution and aldehydes, which leads to a decline of protein solubility, due to aggregations, also supported by (Buttkus, 1966). It seems that the interaction is taking place at some uncovered and new opened sites of unfolded myosin chain. During this interaction myosin solubility, sulphydryl groups and free amino groups significantly decreased, thus supporting the idea of Schiff base and/or Michael addition reaction taking place.

In order to make more visual, we showed some mechanisms and target proteins in the relationship between lipid and protein oxidation products in a schematically graph (Figures 1 and 2).

During postmortem of fish muscle the lack of ATP and anaerobic conditions leading to the antioxidants consumption which are resulted to the oxidation development. Probably during postmortem changes, first metal catalysed oxidation in proteins are dominated followed by lipid oxidation development. We would say maybe protein oxidation started earlier than lipid oxidation or both are in parallel. Therefore, bleeding or washing the muscle after stunning can be considered as a main factor to reduce this interaction. On the other hand, it appears that during frozen storage, formation of secondary products of lipid oxidation has a key role in the lipid-protein interaction via Schiff base reaction in the side chain of amino acids.
Secondary lipid oxidation products might have more impact on the functionality of proteins from both Michael addition and Schiff base reaction rather than lipid hydroperoxides.

\section{5 | CONCLUSION}

The present review summarizes the main actions of protein oxidation and the possible connection to lipid oxidation with a focus on fish quality. Until now, both oxidation processes have been investigated more or less separate from each other. However, both processes occur in parallel in fish and fish products. The reaction products can then react further with each other and form either volatile or non-volatile stable products. Formation of 'induced' protein-lipid complexes is the result of this interaction.

We propose that the products of lipid oxidation promote protein oxidation in fish rather than the other way around specially, during frozen storage. While during postmortem changes, protein oxidation is dominating. This hypothesis needs to be explored in model systems as well as on real fish samples. In addition, a comparison of lean and fatty fish should be made. There is the possibility, that retarding lipid oxidation could also slow down protein oxidation and hence increase shelf life of fish. Furthermore, there is a strong need to investigate how oxidation products influence the kinetics of the ongoing lipid and protein oxidation processes to better prevent oxidation and food spoilage. 
Finally, it seems that, secondary products of lipid oxidation might have more impact on the functionality of proteins from both Michael addition and Schiff base reaction rather than lipid hydroperoxides.

\section{ACKNOWLEDGEMENTS}

The study was financially supported by the Ministry of Education, Youth and Sports of the Czech Republic - projects 'CENAKVA' (No. CZ.1.05/2.1.00/01.0024), 'CENAKVA II' (No. LO1205 under the NPU I program) and GAJU 060/2016/Z.

\section{ORCID}

Nima Hematyar (iD https://orcid.org/0000-0002-7414-2672

Turid Rustad (iD https://orcid.org/0000-0002-8972-6347

Sabine Sampels (iD https://orcid.org/0000-0003-1695-5939

Trine Kastrup Dalsgaard (iD https://orcid.org/0000-0002-5635-4102

\section{REFERENCES}

Adolfo Amici, R. L. L., Tsai, L., \& Stadtman, E. R. (1989). Conversion of amino acid residues in proteins and amino acid homopolymers to carbonyl derivatives by metal-catalyzed oxidation reactions. Journal of Biological Chemistry., 264(6), 3341-3346.

Aeschbach, R., Amadoò, R., \& Neukom, H. (1976). Formation of dityrosine cross-links in proteins by oxidation of tyrosine residues. Biochimica Et Biophysica Acta (BBA) - Protein Structure, 439(2), 292-301. https:// doi.org/10.1016/0005-2795(76)90064-7

Alzagtat, A. A., \& Alli, I. (2002). Protein-lipid interactions in food systems: A review. International Journal of Food Sciences and Nutrition, 53(3), 249-260. https://doi.org/10.1080/09637480220132850

Baron, C. P., Kjaersgard, I. V. H., Jessen, F., \& Jacobsen, C. (2007). Protein and lipid oxidation during frozen storage of rainbow trout (Oncorhynchus mykiss). Journal of Agricultural and Food Chemistry, 55, 8118-8125.

Brjekkan, O. R. (1959). A comparative study of vitamins in the trunk muscles of fishes (Vol. 3). Director of fisheries.

Buttkus, H. (1966). Preparation and properties of trout myosin. Journal of the Fisheries Research Board of Canada, 23(4), 563-573. https://doi. org/10.1139/f66-047

Cai, J., Bhatnagar, A., \& Pierce, W. M. (2009). Protein modification by acrolein: Formation and stability of cysteine adducts. Chemical Research in Toxicology, 22(4), 708-716. https://doi.org/10.1021/tx800465m

Cardoso, D. R., Franco, D. W., Olsen, K., Andersen, M. L., \& Skibsted, L. H. (2004). Reactivity of bovine whey proteins, peptides, and amino acids toward triplet riboflavin as studied by laser flash photolysis. Journal of Agricultural and Food Chemistry, 52(21), 6602-6606. https://doi.org/10.1021/jf0401165

Carlin, K. R. M., Huff-Lonergan, E., Rowe, L. J., \& Lonergan, S. M. (2006). Effect of oxidation, $\mathrm{pH}$, and ionic strength on calpastatin inhibition of $\mu$ - and m-calpain. Journal of Animal Science, 84(4), 925-937. https:// doi.org/10.2527/2006.844925x

Chaijan, M. (2008). Lipid and myoglobin oxidations in muscle foods. Songklanakarin Journal of Science and Technology (SJST), 30, 47-53.

Chan, K. M., \& Decker, E. A. (1994). Endogenous skeletal-muscle antioxidants. Critical Reviews in Food Science and Nutrition, 34(4), 403-426. https://doi.org/10.1080/10408399409527669

Choe, E., \& Min, D. B. (2006). Mechanisms of antioxidants in the oxidation of foods. Comprehensive Reviews in Food Science and Food Safety, 8(4), 345-358. https://doi.org/10.1111/j.1541-4337.2009.00085.x
Chopin, C., Kone, M., \& Serot, T. (2007). Study of the interaction of fish myosin with the products of lipid oxidation: The case of aldehydes. Food Chemistry, 105(1), 126-132. https://doi.org/10.1016/j. foodchem.2007.03.058

Dalsgaard, T. K., Nielsen, J. H., Brown, B. E., Stadler, N., \& Davies, M. J. (2011). Dityrosine, 3,4-dihydroxyphenylalanine (DOPA), and radical formation from tyrosine residues on milk proteins with globular and flexible structures as a result of riboflavin-mediated photo-oxidation. Journal of Agricultural and Food Chemistry, 59(14), 7939-7947. https:// doi.org/10.1021/jf200277r

Dalsgaard, T. K., Nielsen, J. H., \& Larsen, L. B. (2007). Proteolysis of milk proteins lactosylated in model systems. Molecular Nutrition \& Food Research, 51(4), 404-414. https://doi.org/10.1002/mnfr.200600112

Dalsgaard, T. K., Otzen, D., Nielsen, J. H., \& Larsen, L. B. (2007). Changes in structures of milk proteins upon photo-oxidation. Journal of Agricultural and Food Chemistry, 55(26), 10968-10976. https://doi. org/10.1021/jf071948g

Dalsgaard, T. K., Sorensen, J., Bakman, M., Nebel, C., Albrechtsen, R., Vognsen, L., \& Nielsen, J. H. (2011). Light-induced protein and lipid oxidation in low-fat cheeses: Whey proteins as antioxidants. Dairy Science \& Technology, 91(2), 171-183. https://doi.org/10.1007/ s13594-011-0001-1

Dalsgaard, T. K., Sorensen, J., Bakman, M., Vognsen, L., Nebel, C., Albrechtsen, R., \& Nielsen, J. H. (2010). Light-induced protein and lipid oxidation in cheese: Dependence on fat content and packaging conditions. Dairy Science \& Technology, 90(5), 565-577. https://doi. org $/ 10.1051 /$ dst $/ 2010019$

Dalsgaard, T. K., Triquigneaux, M., Deterding, L., Summers, F. A., Mortensen, G., \& Mason, R. P. (2014). Oxidation of $\alpha$-lactalbumin after a lactoperoxidase-catalysed reaction: An oxidomics approach applying immuno-spin trapping and mass spectrometry. International Dairy Journal, 38(2), 154-159. https://doi.org/10.1016/j. idairyj.2013.11.005

Davies, K. J. A., \& Delsignore, M. E. (1987). Protein damage and degradation by oxygen radicals. 3. Modification of secondary and tertiary structure. Journal of Biological Chemistry, 262(20), 9908-9913.

Davies, K. J. A., Delsignore, M. E., \& Lin, S. W. (1987). Protein damage and degradation by oxygen radicals. 2. Modification of amino-acids. Journal of Biological Chemistry, 262(20), 9902-9907.

Di Bernardini, R., Harnedy, P., Bolton, D., Kerry, J., O'Neill, E., Maria Mullen, A., \& Hayes, M. (2011). Antioxidant and antimicrobial peptidic hydrolysates from muscle protein sources and by-products. Food Chemistry, 124(4), 1296-1307. https://doi.org/10.1016/j. foodchem.2010.07.004

Estévez, M. (2015). Oxidative damage to poultry: From farm to fork. Poultry Science, 94(6), 1368-1378. https://doi.org/10.3382/ps/pev094

Estévez, M., \& Cava, R. (2004). Lipid and protein oxidation, release of iron from heme molecule and colour deterioration during refrigerated storage of liver pâté. Meat Science, 68(4), 551-558. https://doi. org/10.1016/j.meatsci.2004.05.007

Estevez, M., Morcuende, D., Ventanas, S., \& Cava, R. (2003). Analysis of volatiles in meat from Iberian pigs and lean pigs after refrigeration and cooking by using SPME-GC-MS. Journal of Agricultural and Food Chemistry, 51(11), 3429-3435. https://doi.org/10.1021/jf026218h

Estévez, M., Ventanas, S., \& Cava, R. (2005). Physicochemical properties and oxidative stability of liver pâté as affected by fat content. Food Chemistry, 92(3), 449-457. https://doi.org/10.1016/j. foodchem.2004.08.014

Fedorova, M., Bollineni, R. C., \& Hoffmann, R. (2014). Protein carbonylation as a major hallmark of oxidative damage: Update of analytical strategies. Mass Spectrometry Reviews, 33(2), 79-97. https://doi. org/10.1002/mas.21381

Fillery-Travis, A., Mills, E. N. C., \& Wilde, P. (2000). Protein-lipid interactions at interfaces. Grasas Y Aceites, 51(1-2), 50-55. https://doi. org/10.3989/gya.2000.v51.i1-2.406 
Foote, C. S. (1976). Photosensitized oxidation and singlet oxygen: Consequences in biological systems. Free Radicals in Biology, 2, 85-133.

Gardner, H. W. (1979). Lipid hydroperoxide reactivity with proteins and amino acids: A review. Journal of Agricultural and Food Chemistry, 27(2), 220-229. https://doi.org/10.1021/jf60222a034

Gitlin, I., Carbeck, J. D., \& Whitesides, G. M. (2006). Why are proteins charged? Networks of charge-charge interactions in proteins measured by charge ladders and capillary electrophoresis. Angewandte Chemie International Edition, 45(19), 3022-3060. https://doi. org/10.1002/anie.200502530

Guiotto, A., Calderan, A., Ruzza, P., \& Borin, G. (2005). Carnosine and carnosine-related antioxidants: A review. Current Medicinal Chemistry, 12(20), 2293-2315. https://doi.org/10.2174/0929867054864796

Hawkins, C. L., \& Davies, M. J. (2001). Generation and propagation of radical reactions on proteins. Biochimica Et Biophysica Acta-Bioenergetics, 1504(2-3), 196-219. https://doi.org/10.1016/ s0005-2728(00)00252-8

Heinonen, I. M., Meyer, A. S., \& Frankel, E. N. (1998). Antioxidant activity of berry phenolics on human low-density lipoprotein and liposome oxidation. Journal of Agriculture and Food Chemistry, 46(10), 41074112. https://doi.org/10.1021/jf980181c

Hematyar, N., Masilko, J., Mraz, J., \& Sampels, S. (2018). Nutritional quality, oxidation, and sensory parameters in fillets of common carp (Cyprinus carpio L.) influenced by frozen storage $\left(-20^{\circ} \mathrm{C}\right)$. Journal of Food Processing and Preservation., https://doi.org/10.1111/ jfpp.13589

Hidalgo, F. J., \& Zamora, R. (2000). The role of lipids in nonenzymatic browning [Amino-carbonyl reactions; Maillard reaction; Nonenzymatic browning; Oxidized lipid-protein interactions]. Grasas Y Aceites, 51(1-2), 1-2. https://doi.org/10.3989/gya.2000.v51. i1-2.405

Hohn, A., Jung, T., Grimm, S., Catalgol, B., Weber, D., \& Grune, T. (2011). Lipofuscin inhibits the proteasome by binding to surface motifs. Free Radical Biology and Medicine, 50(5), 585-591. https://doi. org/10.1016/j.freeradbiomed.2010.12.011

Howell, N. K., Herman, H., \& Li-Chan, E. C. Y. (2001). Elucidation of protein-lipid interactions in a lysozyme-corn oil system by Fourier transform Raman spectroscopy. Journal of Agricultural and Food Chemistry, 49(3), 1529-1533. https://doi.org/10.1021/jf001115p

Huff-Lonergan, E., \& Lonergan, S. M. (2005). Mechanisms of waterholding capacity of meat: The role of postmortem biochemical and structural changes. Meat Science, 71(1), 194-204. https://doi. org/10.1016/j.meatsci.2005.04.022

Jensen, F. B. (2001). Comparative analysis of autoxidation of haemoglobin. Journal of Experimental Biology, 204(11), 2029-2033.

Jeremiah, L. E. (2001). Packaging alternatives to deliver fresh meats using short- or long-term distribution. Food Research International, 34(9), 749-772. https://doi.org/10.1016/S0963-9969(01)00096-5

Jonsson, A., Olsen, R. E., Hyldig, G., Nielsen, H. H., Jorgensen, B., Larsson, K., ... Hafssteinsson, H. (2007). Improved quality of herring for humans Nordic Innovation Centre (NICe) project number: 0210678.

Jung, T., Hohn, A., \& Grune, T. (2014). The proteasome and the degradation of oxidized proteins: Part II - protein oxidation and proteasomal degradation. Redox Biology, 2, 99-104. https://doi.org/10.1016/j. redox.2013.12.008

Kim, Y. H., Huff-Lonergan, E., Sebranek, J. G., \& Lonergan, S. M. (2010). High-oxygen modified atmosphere packaging system induces lipid and myoglobin oxidation and protein polymerization. Meat Science, 85(4), 759-767. https://doi.org/10.1016/j.meatsci.2010.04.001

Kjaersgard, I. V. H., \& Jessen, F. (2004). Two-dimensional gel electrophoresis detection of protein oxidation in fresh and tainted rainbow trout muscle. [Article]. Journal of Agricultural and Food Chemistry, 52(23), 7101-7107. https://doi.org/10.1021/jf049573b
Kramer, R. M., Shende, V. R., Motl, N., Pace, C. N., \& Scholtz, J. M. (2012). Toward a molecular understanding of protein solubility: Increased negative surface charge correlates with increased solubility. Biophysical Journal, 102(8), 1907-1915. https://doi.org/10.1016/j. bpj.2012.01.060

Kubow, S. (1992). Routes of formation and toxic consequences of lipid oxidation-products in foods. Free Radical Biology and Medicine, 12(1), 63-81. https://doi.org/10.1016/0891-5849(92)90059-p

Ladikos, D., \& Lougovois, V. (1990). Lipid oxidation in muscle foods - a review. Food Chemistry, 35(4), 295-314. https://doi. org/10.1016/0308-8146(90)90019-Z

Liang, J. H. (1999). Fluorescence due to interactions of oxidizing soybean oil and soy proteins. Food Chemistry, 66(1), 103-108. https://doi. org/10.1016/s0308-8146(98)00250-7

Liu, R., Xing, L. J., Fu, Q. Q., Zhou, G. H., \& Zhang, W. G. (2016). A review of antioxidant peptides derived from meat muscle and by-products. Antioxidants, 5(3), 32. https://doi.org/10.3390/antiox5030032

Lund, M. N., Heinonen, M., Baron, C. P., \& Estevez, M. (2011). Protein oxidation in muscle foods: A review. Molecular Nutrition \& Food Research, 55(1), 83-95. https://doi.org/10.1002/mnfr.201000453

Lynch, M. P., \& Faustman, C. (2000). Effect of aldehyde lipid oxidation products on myoglobin. Journal of Agricultural and Food Chemistry, 48(3), 600-604. https://doi.org/10.1021/jf990732e

Maqsood, S., \& Benjakul, S. (2011). Comparative studies on molecular changes and pro-oxidative activity of haemoglobin from different fish species as influenced by $\mathrm{pH}$. Food Chemistry, 124(3), 875-883. https://doi.org/10.1016/j.foodchem.2010.07.01

Maqsood, S., Benjakul, S., \& Kamal-Eldin, A. (2012). Haemoglobin-mediated lipid oxidation in the fish muscle: A review. Trends in Food Science \& Technology, 28(1), 33-43. https://doi.org/10.1016/j. tifs.2012.06.009

Maqsood, S., Singh, P., Samoon, M. H., \& Munir, K. (2011). Emerging role of immunostimulants in combating the disease outbreak in aquaculture. International Aquatic Research, 3(3), 147-163.

Martinaud, A., Mercier, Y., Marinova, P., Tassy, C., Gatellier, P., \& Renerre, M. (1997). Comparison of oxidative processes on myofibrillar proteins from beef during maturation and by different model oxidation systems. Journal of Agricultural and Food Chemistry, 45(7), 2481-2487. https://doi.org/10.1021/jf960977g

Medina, I., Gallardo, J. M., \& Aubourg, S. P. (2009). Quality preservation in chilled and frozen fish products by employment of slurry ice and natural antioxidants. [Review]. International Journal of Food Science and Technology, 44(8), 1467-1479. https://doi. org/10.1111/j.1365-2621.2009.02016.x

Meng, G. T., Chan, J. C. K., Rousseau, D., \& Li-Chan, E. C. Y. (2005). Study of protein - Lipid interactions at the bovine serum albumin/oil interface by Raman microspectroscopy. Journal of Agricultural and Food Chemistry, 53(4), 845-852. https://doi.org/10.1021/jf040259r

Metz, B., Kersten, G. F. A., Hoogerhout, P., Brugghe, H. F., Timmermans, H. A. M., de Jong, A., ... Jiskoot, W. (2004). Identification of formaldehyde-induced modifications in proteins - Reactions with model peptides. Journal of Biological Chemistry, 279(8), 6235-6243. https:// doi.org/10.1074/jbc.M310752200

Moller, I. M., Rogowska-Wrzesinska, A., \& Rao, R. S. P. (2011). Protein carbonylation and metal-catalyzed protein oxidation in a cellular perspective. Journal of Proteomics, 74(11), 2228-2242. https://doi. org/10.1016/j.jprot.2011.05.004

Mozuraityte, R., Kristinova, V., Rustad, T., \& Storro, I. (2016). The role of iron in peroxidation of PUFA: Effect of $\mathrm{pH}$ and chelators. European Journal of Lipid Science and Technology, 118(4), 658-668. https://doi. org/10.1002/ejlt.201400590

Nielsen, M. K., \& Jorgensen, B. M. (2004). Quantitative relationship between trimethylamine oxide aldolase activity and formaldehyde accumulation in white muscle from gadiform fish during frozen storage. 
Journal of Agricultural and Food Chemistry, 52(12), 3814-3822. https:// doi.org/10.1021/jf035169|

Nystrom, T. (2005). Role of oxidative carbonylation in protein quality control and senescence. EMBO Journal, 24(7), 1311-1317. https:// doi.org/10.1038/sj.emboj.7600599

Østdal, H., Davies, M. J., \& Andersen, H. J. (2002). Reaction between protein radicals and other biomolecules. Free Radical Biology and Medicine, 33(2), 201-209. https://doi.org/10.1016/S0891-5849(02)00785-2

Papuc, C., Goran, G. V., Predescu, C. N., \& Nicorescu, V. (2017). Mechanisms of oxidative processes in meat and toxicity induced by postprandial degradation products: A review. Comprehensive Reviews in Food Science and Food Safety, 16(1), 96-123. https://doi. org/10.1111/1541-4337.12241

Passarelli, C., Di Venere, A., Piroddi, N., Pastore, A., Scellini, B., Tesi, C., ... Piemonte, F. (2010). Susceptibility of isolated myofibrils to in vitro glutathionylation: Potential relevance to muscle functions. Cytoskeleton, 67(2), 81-89. https://doi.org/10.1002/cm.20425

Patel, B. G., Wilder, T., \& Solaro, R. J. (2013). Novel control of cardiac myofilament response to calcium by S-glutathionylation at specific sites of myosin binding protein C. Frontiers in Physiology, 4, 33610.3389/ fphys.2013.00336

Pizzimenti, S., Ciamporcero, E., Daga, M., Pettazzoni, P., Arcaro, A., Cetrangolo, G., ... Barrera, G. (2013). Interaction of aldehydes derived from lipid peroxidation and membrane proteins. Frontiers in Physiology, 4, 24210.3389/fphys.2013.00242

Powers, D. A. (1972). Hemoglobin adaptation for fast and slow water habitats in sympatric catostomid fishes. Science, 177(4046), 360 362. https://doi.org/10.1126/science.177.4046.360

Ranathunga, S., Rajapakse, N., \& Kim, S. K. (2006). Purification and characterization of antioxidative peptide derived from muscle of conger eel (Conger myriaster). European Food Research and Technology, 222(34), 310-315. https://doi.org/10.1007/s00217-005-0079-x

Reeg, S., \& Grune, T. (2015). Protein oxidation in toxicology. In S. M. Roberts, J. P. Kehrer, \& L.-O. Klotz (Eds.), Studies on experimental toxicology and pharmacology (pp. 81-102). Cham: Springer International Publishing.

Refsgaard, H. H. F., Tsai, L., \& Stadtman, E. R. (2000). Modifications of proteins by polyunsaturated fatty acid peroxidation products. Proceedings of the National Academy of Sciences of the United States of America, 97(2), 611-616. https://doi.org/10.1073/pnas.97.2.611

Requena, J. R., Chao, C. C., Levine, R. L., \& Stadtman, E. R. (2001). Glutamic and aminoadipic semialdehydes are the main carbonyl products of metal-catalyzed oxidation of proteins. Proceedings of the National Academy of Sciences of the United States of America, 98(1), 69-74. https://doi.org/10.1073/pnas.011526698

Richards, M. P., \& Hultin, H. O. (2002). Contributions of blood and blood components to lipid oxidation in fish muscle. Journal of Agricultural and Food Chemistry, 50(3), 555-564. https://doi.org/10.1021/ jf010562h

Richards, M. P., \& Hultin, H. O. (2003). Effects of added hemolysate from mackerel, herring and rainbow trout on lipid oxidation of washed cod muscle. Fisheries Science, 69(6), 1298-1300. https://doi. org/10.1111/j.0919-9268.2003.00758.x

Richards, M. P., Ostdal, H., \& Andersen, H. J. (2002). Deoxyhemoglobinmediated lipid oxidation in washed fish muscle. Journal of Agricultural and Food Chemistry, 50(5), 1278-1283. https://doi.org/10.1021/ jf011093m

Rowe, L. J., Maddock, K. R., Lonergan, S. M., \& Huff-Lonergan, E. (2004). Influence of early postmortem protein oxidation on beef quality. Journal of Animal Science, 82(3), 785-793.

Saeed, S., Fawthrop, S. A., \& Howell, N. K. (1999). Electron spin resonance (ESR) study on free radical transfer in fish lipid-protein interaction. Journal of the Science of Food and Agriculture, 79(13), 1809-1816. https://doi.org/10.1002/ (sici)1097-0010(199910)79:13<1809:aid-jsfa440>3.0.co;2-v
Saeed, S., \& Howell, N. K. (2002). Effect of lipid oxidation and frozen storage on muscle proteins of Atlantic mackerel (Scomber scombrus). Journal of the Science of Food and Agriculture, 82(5), 579-586. https:// doi.org/10.1002/jsfa.1080

Saito, K., Jin, D. H., Ogawa, T., Muramoto, K., Hatakeyama, E., Yasuhara, T., \& Nokihara, K. (2003). Antioxidative properties of tripeptide libraries prepared by the combinatorial chemistry. Journal of Agricultural and Food Chemistry, 51(12), 3668-3674. https://doi.org/10.1021/jf021191n

Sampels, S. (2013). Oxidation and antioxidants in fish and meat from farm to fork.

Sarma, J., Vidya Sagar Reddy, G., \& Srikar, L. N. (2000). Effect of frozen storage on lipids and functional properties of proteins of dressed Indian oil sardine (Sardinella longiceps). Food Research International, 33(10), 815-820. https://doi.org/10.1016/S0963-9969(00)00077-6

Schaich, K. M., \& Karel, M. (1976). Free radical reactions of peroxidizing lipids with amino acids and proteins: An ESR study. Lipids, 11(5), 392-400. https://doi.org/10.1007/BF02532846

Secci, G., \& Parisi, G. (2016). From farm to fork: Lipid oxidation in fish products. A review. Italian Journal of Animal Science, 15(1), 124-136. https://doi.org/10.1080/1828051x.2015.1128687

Soladoye, O. P., Juarez, M. L., Aalhus, J. L., Shand, P., \& Estevez, M. (2015). Protein oxidation in processed meat: Mechanisms and potential implications on human health. Comprehensive Reviews in Food Science and Food Safety, 14(2), 106-122. https://doi.org/10.1111/1541-4337.12127

Soyer, A., \& Hultin, H. O. (2000). Kinetics of oxidation of the lipids and proteins of cod sarcoplasmic reticulum. Journal of Agriculture and Food Chemistry., 48(6), 2127-2134. https://doi.org/10.1021/jf990780z

Soyer, A., Özalp, B., Dalmış, Ü., \& Bilgin, V. (2010). Effects of freezing temperature and duration of frozen storage on lipid and protein oxidation in chicken meat. Food Chemistry, 120(4), 1025-1030. https:// doi.org/10.1016/j.foodchem.2009.11.042

Stadtman, E. R. (1990). Metal ion-catalyzed oxidation of proteins - biochemical-mechanism and biological consequences. Free Radical Biology and Medicine, 9(4), 315-325. https://doi. org/10.1016/0891-5849(90)90006-5

Stadtman, E. R. (1993). Oxidation of free amino-acids and amino-acidresidues in proteins by radiolysis and by metal-catalyzed reactions. Annual Review of Biochemistry, 62, 797-821. https://doi.org/10.1146/ annurev.bi.62.070193.004053

Stadtman, E. R. (2006). Protein oxidation and aging. Free Radical Research, 40(12), 1250-1258. https://doi.org/10.1080/10715760600918142

Stadtman, E. R., \& Levine, R. L. (2000). Protein oxidation. Annals of the New York Academy of Sciences, 899, 191-208. https://doi. org/10.1111/j.1749-6632.2000.tb06187.x

Stadtman, E. R., \& Levine, R. L. (2003). Free radical-mediated oxidation of free amino acids and amino acid residues in proteins. Amino Acids, 25(3-4), 207-218. https://doi.org/10.1007/s00726-003-0011-2

Standal, I. B., Mozuraityte, R., Rustad, T., Alinasabhematabadi, L., Carlsson, N. G., \& Undeland, I. (2018). Quality of filleted Atlantic mackerel (Scomber scombrus) during chilled and frozen storage: Changes in lipids, vitamin D, proteins, and small metabolites, including biogenic amines. Journal of Aquatic Food Product Technology, 27(3), 338-357. https://doi.org/10.1080/10498850.2018.1436107

Subbaiah, K., Majumdar, R. K., Choudhury, J., Priyadarshini, B. M., Dhar, B., Roy, D., ... Maurya, P. (2015). Protein degradation and instrumental textural changes in fresh nile tilapia (Oreochromis niloticus) during frozen storage. Journal of Food Processing and Preservation, 39(6), 2206-2214. https://doi.org/10.1111/jfpp.12465

Viljanen, K., Kylli, P., Hubbermann, E. M., Schwarz, K., \& Heinonen, M. (2005). Anthocyanin antioxidant activity and partition behavior in whey protein emulsion. Journal of Agricultural and Food Chemistry, 53(6), 2022-2027. https://doi.org/10.1021/jf047975d

Xiong, Y. L. (2000). Protein oxidation and implications for muscle foods quality. In E. Decker, C. Faustman, \& C. J. Lopez-Bote (Eds.), Xxxx (pp. $85-111)$. ref. 163 
Yin, X., Luo, Y., Fan, H., Wu, H., \& Feng, L. (2014). Effect of previous frozen storage on quality changes of grass carp (Ctenopharyngodon idellus) fillets during short-term chilled storage. International Journal of Food Science \& Technology, 49(6), 1449-1460. https://doi.org/10.1111/ ijfs.12431

Zhang, W. G., Xiao, S., \& Ahn, D. U. (2013). Protein oxidation: Basic principles and implications for meat quality. Critical Reviews in Food Science and Nutrition, 53(11), 1191-1201. https://doi.org/10.1080/1040839 8.2011.577540
How to cite this article: Hematyar N, Rustad T, Sampels S, Kastrup Dalsgaard T. Relationship between lipid and protein oxidation in fish. Aquac Res. 2019;50:1393-1403. https://doi. org/10.1111/are.14012 